\title{
Determination of Titanium Dioxide Content in Bauxites Using X-ray Fluorescence Spectrometry by Fusion and by Pressing
}

\author{
Dragana Blagojević,,${ }^{1, \star}$ Dragica Lazić, ${ }^{2}$ Dragana Kešelj, ${ }^{2}$ Gordana Ostojić ${ }^{3}$ \\ and Mugdin Imamović ${ }^{4}$ \\ ${ }^{1}$ Department of Chemistry, Faculty of Natural Sciences and Mathematics, University of Banja Luka, Mladena Stojanovića 2, \\ 78000 Banja Luka, BiH \\ ${ }^{2}$ Department of Chemical Technology, Faculty of Technology, University of East Sarajevo, Karakaj bb, 75400 Zvornik, BiH \\ ${ }^{3}$ Alumina Factory “Alumina” Zvornik, Karakaj, 75400 Zvornik, BiH \\ ${ }^{4}$ Cement Factory "Lukavac", Lukavačkih brigada bb, 75300 Lukavac, BiH \\ *Corresponding author: E-mail: dragana_blagojevic@yahoo.com \\ Tel.: +38765870 534
}

Received: $15-12-2017$

\begin{abstract}
Bauxites of different deposits were analysed for their content of $\mathrm{TiO}_{2}$ (mass \%), using X-ray fluorescence spectrometry and the reference spectrophotometric method JUS B.G8.514. The samples were prepared in two ways: fusion with a borax technique and pressing, after which beads were formed for the purpose of analysis. Certified reference samples of bauxite were used for producing a calibration curve. The equation for calculating the content of $\mathrm{TiO}_{2}(\mathrm{mass} \%)$ in the samples of bauxite was derived from the calibration curve. Results of the XRF method were tested statistically by means of the F-test and the t-test (the standard sample of the bauxite and the reference method). The values obtained from the afore mentioned tests for the fusion beads showed that the XRF method was precise and correct and that there were no systematic errors, whereas for the pressed beads this method showed significant systematic errors.
\end{abstract}

Keywords: XRF analysis, bauxite, titanium dioxide

\section{Introduction}

Bauxite is the principal ore for producing aluminium metal via a two-stage process that involves, firstly, the refining of bauxite to alumina through a wet chemical caustic leach process (the Bayer process) and, secondly, the electrolytic reduction of alumina to aluminium metal (the Hall-Heroult process). ${ }^{1}$ The remaining bauxite is used in the refractory, abrasive and chemical industries. ${ }^{2}$

The main minerals that are present in bauxite include several forms of hydrated aluminium oxide: gibbsite $\left(\mathrm{Al}_{2} \mathrm{O}_{3}\right.$ - $\left.3 \mathrm{H}_{2} \mathrm{O}\right)$, boehmite $\left(\mathrm{Al}_{2} \mathrm{O}_{3} \cdot \mathrm{H}_{2} \mathrm{O}\right)$, and diaspore $\left(\mathrm{Al}_{2} \mathrm{O}_{3}\right.$. $\mathrm{H}_{2} \mathrm{O}$ ). In addition to these, the rock also contains significant quantities of the following minerals: corundum, goethite, hematite, kaolinite, halloysite, anatase, and rutile. ${ }^{3}$ This means that, in addition to the aluminium mineral, the main components of bauxite are the following elements: iron, silicon, titanium, calcium, and magnesium. The mixture may also contain minerals of a series of other elements: $\mathrm{Na}, \mathrm{K}, \mathrm{P}, \mathrm{Cr}, \mathrm{V}, \mathrm{Ga}, \mathrm{Zn}, \mathrm{Pb}, \mathrm{Cu}, \mathrm{Ni}, \mathrm{Mn}, \mathrm{Co}$, and others. ${ }^{4}$

The mineralogy of bauxite deposits controls the efficacy of the Bayer process. Some of the gangue components, such as clays, fine-grained quartz, and titanium oxides, are deleterious as they react with the leaching solution, which causes caustic soda losses in the Bayer process. ${ }^{1}$

Bauxite usually contains $2-4$ mass $\%$ of $\mathrm{TiO}_{2} \cdot \mathrm{TiO}_{2}$ exists in the form such as anatase, rutile and brookite minerals. ${ }^{5}$

Various methods have been used for determining titanium content in different types of samples, such as: inductively coupled plasma-atomic emission spectrometry (ICP-AES), ${ }^{6}$ inductively coupled plasma-mass spectrometry (ICP-MS), ${ }^{7}$ graphite furnace atomic absorption spec- 
trometry (GFAAS), ${ }^{8}$ catalytic adsorptive stripping voltammetry (CASV), ${ }^{9}$ neutron activation analysis (NAA), ${ }^{10}$ spectrophotometry, ${ }^{11,12,13} \mathrm{X}$-ray fluorescence (XRF), ${ }^{14}$ and laser induced breakdown spectroscopy (LIBS). ${ }^{15}$

Chemical composition of bauxite is usually expressed in the content of $\mathrm{Al}_{2} \mathrm{O}_{3}, \mathrm{SiO}_{2}, \mathrm{Fe}_{2} \mathrm{O}_{3}, \mathrm{TiO}_{2}$, and $\mathrm{CaO}$, with the loss on ignition at $1075^{\circ} \mathrm{C}$. In the alumina factory "Alumina", chemical determination of $\mathrm{TiO}_{2}$ content in bauxite is carried out using the spectrophotometric method JUS B.G8.514.

$\mathrm{X}$-ray fluorescence spectrometry is a technique for the analysis of bulk specimens. It is based on the interaction of X-rays with atoms in the sample. ${ }^{16}$ Each of the elements present in a sample produces a set of characteristic fluorescent X-rays ("a fingerprint") that is unique for that specific element, which is why XRF spectroscopy is an excellent technology for qualitative and quantitative analysis of material composition. ${ }^{17}$

$\mathrm{XRF}$ is widely used for environmental, industrial, pharmaceutical, forensic, and scientific research applications to determine the presence or absence and, in some cases, to measure the concentration of elemental constituents or contaminants. ${ }^{18}$

Some examples in which the XRF technique was used are: determination of the chemical composition of different bauxites, ${ }^{19,20}$ bauxitic-based ceramic proppants, ${ }^{21}$ brown fused alumina, ${ }^{22}$ red mud (bauxite residue), ${ }^{23,24,25}$ determination of trace elements in rocks, soils, and sediments, ${ }^{26}$ analysis of ceramic oxide refractories. ${ }^{27}$

\section{Experimental}

Bauxites labelled "Brazil", "Grčka", and "Mađarska", prepared in alumina factory "Alumina", in Zvornik, BiH, were used for the experimental part of the research.
Bauxite samples were first ground to particle size below $200 \mu \mathrm{m}$ and dried, and then annealed at $1075^{\circ} \mathrm{C}$. The loss on ignition was calculated at that temperature.

In the XRF analysis, for the purpose of the preparation of fused beads, $1 \mathrm{~g}$ of the annealed sample was separated and mixed with $8 \mathrm{~g}$ of $\mathrm{Li}_{2} \mathrm{~B}_{4} \mathrm{O}_{7}$ in a platinum pot. After gentle stirring, using a glass rod, the pot was mounted on the "VULCAN" fusion system from Fluxana. After 15 min of melting at around $1250{ }^{\circ} \mathrm{C}$, the sample was poured into a heated platinum mould. After cooling for $10 \mathrm{~min}$, the bead obtained in this way was recorded by WDXRF “S8 TIGER” (BRUKER).

For the purpose of preparing pressed beads, $47.5 \mathrm{~g}$ of the annealed sample was separated and mixed with $2.5 \mathrm{~g}$ of wax and ground in a mill. The sample prepared in this way $(10 \mathrm{~g})$ was then transferred to the mould in the press and subjected to the pressure of $150 \mathrm{KN}$ for $10 \mathrm{~s}$.

The calibration curve was obtained based on the certified reference bauxite samples, which were also annealed prior to the process (Table 1).

One series of samples was prepared by fusion and poured into moulds for beads, and the other series was prepared by pressing in the moulds. The samples were recorded afterwards.

The parameters in the process of recording titanium were as follows: Line Ti KA1, Mask: $34 \mathrm{~mm}$, Mode: Vacuum, $50 \mathrm{kV}, 60 \mathrm{~mA}$, Filter: None, Crystal (nominal): $2 \mathrm{~d}=$ $4.026 \AA$, Collimator aperture (nominal) $=0.46$ degrees, Detector: flow counter LLD $=50, \mathrm{ULD}=150 \%$ of nominal peak, Adjusted peak at 86.101 degrees 2-theta, Wavelength $=2.7485 \AA$.

Spectrophotometric analysis involved the preparation of solutions by fusing the sample with a mixture of $\mathrm{Na}_{2} \mathrm{CO}_{3}$ and $\mathrm{Na}_{2} \mathrm{~B}_{4} \mathrm{O}_{7}$ (3:1), according to a modified method JUS B.G8. 520/92 and ISO 6994/86. A UV-VIS spectro-

Table 1. Analysis of standard reference bauxite samples according to the certificate (mass \%)

\begin{tabular}{lccccc}
\hline Components & $\begin{array}{c}\text { 69b NBS } \\
\text { (Arkansas) }\end{array}$ & $\begin{array}{c}\text { 696 NBS } \\
\text { (Surinam) }\end{array}$ & $\begin{array}{c}\text { 697 NBS } \\
\text { (Dominican) }\end{array}$ & $\begin{array}{c}\text { 698 NBS } \\
\text { (Jamaican) }\end{array}$ & BXT-09 \\
\hline $\mathrm{Al}_{2} \mathrm{O}_{3}$ & 48.80 & 54.50 & 45.80 & 48.20 & 53.40 \\
$\mathrm{BaO}$ & 0.008 & 0.004 & 0.015 & 0.008 & - \\
$\mathrm{CaO}$ & 0.13 & 0.018 & 0.71 & 0.62 & 0.010 \\
$\mathrm{Co}$ & 0.0001 & 0.00009 & 0.0013 & 0.0045 & - \\
$\mathrm{Cr}_{2} \mathrm{O}_{3}$ & 0.011 & 0.047 & 0.100 & 0.080 & 0.037 \\
$\mathrm{Fe}_{2} \mathrm{O}_{3}$ & 7.14 & 8.70 & 20.00 & 19.60 & 14.15 \\
$\mathrm{MgO}_{\mathrm{MnO}}$ & 0.085 & 0.012 & 0.18 & 0.058 & 0.03 \\
$\mathrm{P}_{2} \mathrm{O}_{5}$ & 0.110 & 0.004 & 0.41 & 0.38 & 0.04 \\
$\mathrm{~K}_{2} \mathrm{O}$ & 0.118 & 0.050 & 0.97 & 0.37 & 0.07 \\
$\mathrm{SiO}_{2}$ & 0.068 & 0.009 & 0.062 & 0.010 & - \\
$\mathrm{Na}_{2} \mathrm{O}$ & 13.43 & 3.79 & 6.81 & 0.69 & 7.57 \\
$\mathrm{SO}_{3}$ & 0.025 & 0.007 & 0.036 & 0.015 & - \\
$\mathrm{TiO}_{2}$ & 0.63 & 0.21 & 10.13 & 0.22 & - \\
$\mathrm{V}_{2} \mathrm{O}_{5}$ & 1.90 & 2.64 & 2.52 & 2.38 & 2.98 \\
$\mathrm{Loss}$ on Ignition & 0.028 & 0.072 & 0.063 & 0.064 & 0.06 \\
\hline
\end{tabular}


photometer Lambda 25 Perkin Elmer was used for measurement.

Mineralogical characterization of all the samples of bauxite was carried out using X-ray diffraction (XRD analysis) on a powder diffractometer PHILIPS PW 171. Radiation from the copper anticathode with the wavelength of $\mathrm{CuKa}=1.54178 \AA$ and a graphite monochromator were used for the analysis. The operating voltage on the tube was $\mathrm{U}=40 \mathrm{kV}$, and the current intensity was $\mathrm{I}=30 \mathrm{~mA}$. Samples were tested in the range $2 \theta 5-50^{\circ}$ and with time retention of 1 s at each step. X'Pert Quantify computer software was used for instrument manipulation, whereas X'Pert HighScore was used for data processing.

\section{Results and Discussion}

According to XRD analysis and the obtained diffractograms, the standard reference samples of bauxite have the following mineralogical composition:

- Standard NBS 69b is a typical hydrargillite bauxite. In addition to gibbsite, this sample also contains kaolinite, hematite, goethite, and siderite (Figure 1).

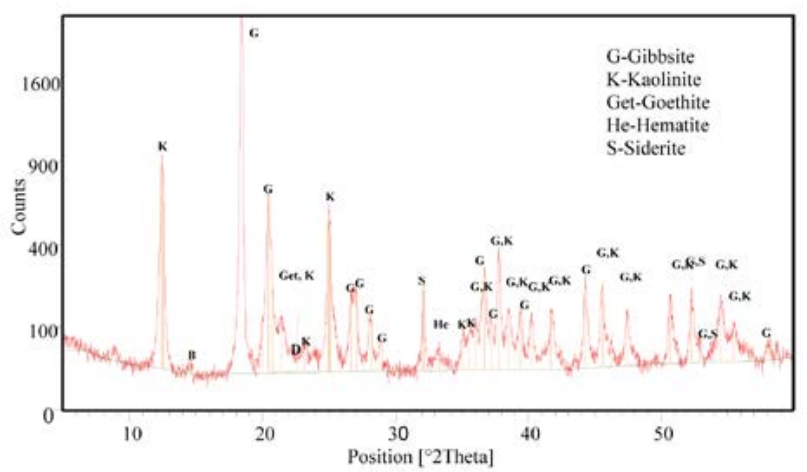

Figure 1. Diffractogram of the standard bauxite sample NBS 69b (Arkansas)

- Standard NBS 696 is a typical hydrargillite bauxite. In addition to gibbsite, this sample of bauxite also contains small traces of hematite, anatase, goethite, kaolinite, and pyrite (Figure 2).

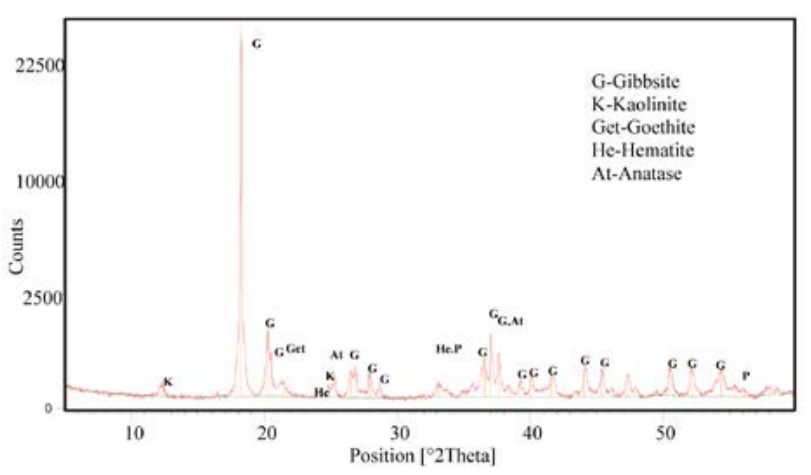

Figure 2. Diffractogram of the standard bauxite sample NBS 696 (Surinam)
- Standard NBS 697 is a combined, gibbsite-boehmite type, with hematite content. In addition to the afore mentioned minerals, the sample also contains goethite and kaolinite, whereas anatase and calcinite are found in traces (Figure 3).

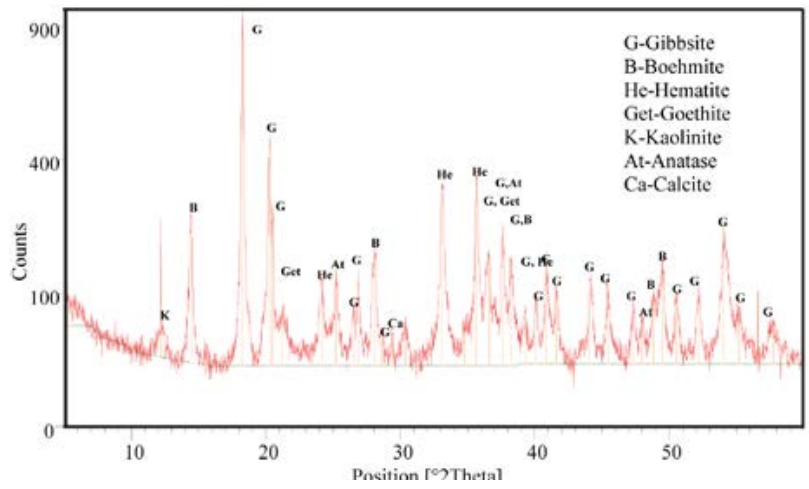

Figure 3. Diffractogram of the standard bauxite sample NBS 697 (Dominican)

- Standard NBS 698 is a hydrargillite bauxite with hematite content. In addition to gibbsite, this sample also contains anatase, goethite, and hematite (Figure 4).

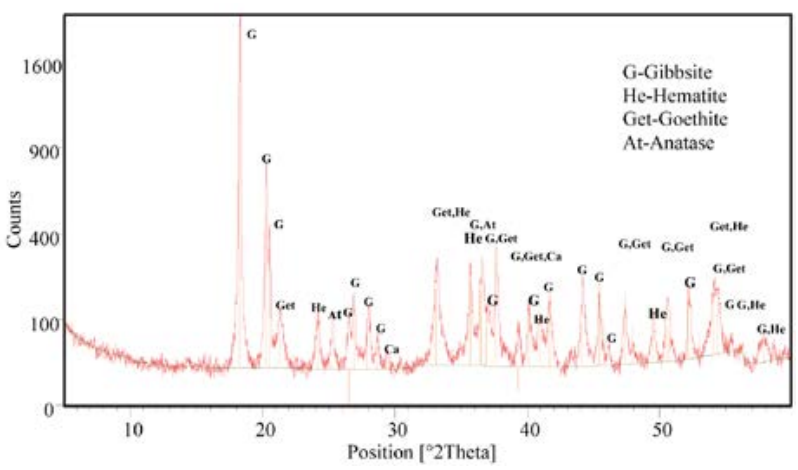

Figure 4. Diffractogram of the standard bauxite sample NBS 698 (Jamaican)

- Standard BXT 09 is a combined gibbsite-boehmite type of bauxite with hematite content. In addition to those

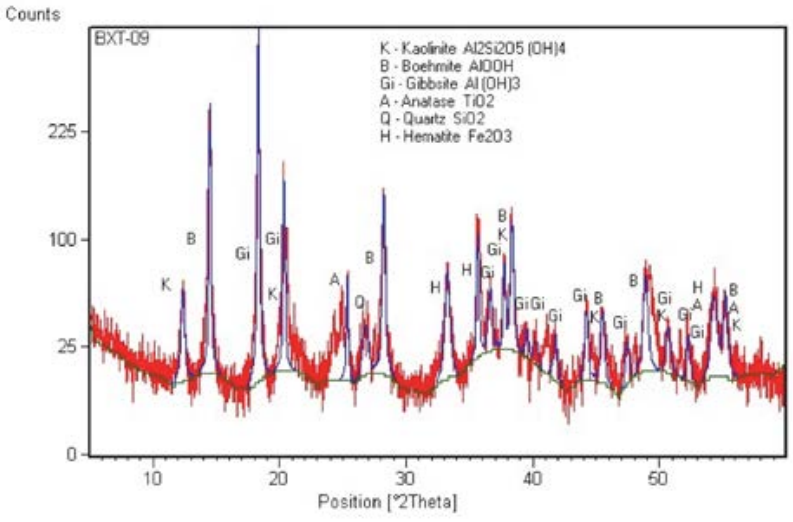

Figure 5. Diffractogram of the standard bauxite sample BXT-09 
minerals, the sample also contains kaolinite, whereas anatase and quartz occur in traces (Figure 5).

According to the XRD analysis, the bauxite samples from different deposits ("Brazil", "Grčka", and "Mađarska") have the following mineralogical composition:

- "Brazil" is a typical hydrargillite type of bauxite. In addition to gibbsite, this sample contains boehmite, hematite, anatase, and kaolinite, all in traces (Figure 6).

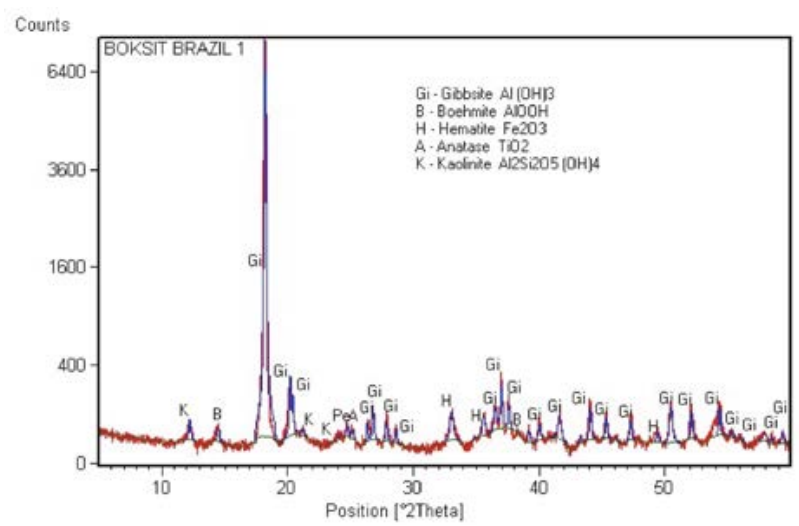

Figure 6. Diffractogram of the bauxite sample "Brazil"

- "Grčka" bauxite is diaspore bauxite with a boehmite and hematite contents. In addition to those minerals, the sample also contains calcite and anatase, whereas quartz, kaolinite, gibbsite, goethite, and rutile are present in traces (Figure 7).

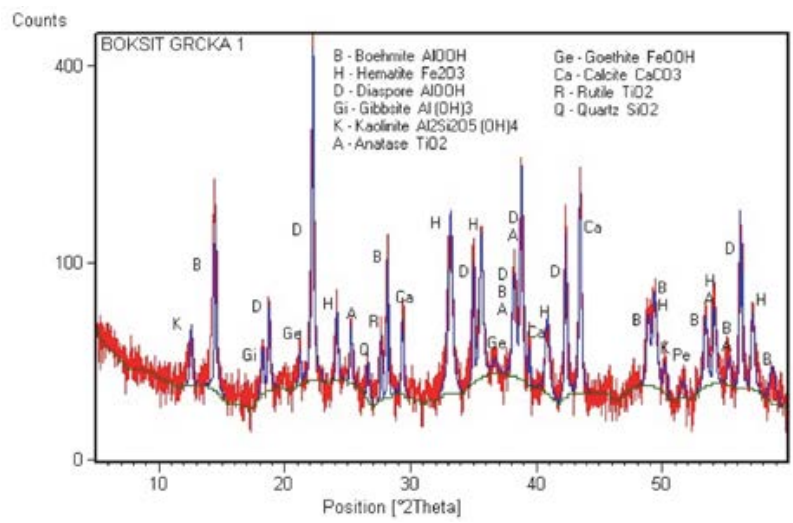

Figure 7. Diffractogram of the bauxite sample "Grčka"

- "Mađarska" is a gibbsite-boehmite combination with hematite and kaolinite contents. In addition to these minerals, the sample also contains goethite and traces of anatase and rutile (Figure 8).

Calibration curves were created based on data for standard certified reference samples of bauxite and the obtained values of intensity (Net) for the samples prepared by fusion and pressing (Figure 9 and Figure 10). The content of $\mathrm{TiO}_{2}$, which was taken as the basis for the development of the calibration curve, was calculated for an absolutely annealed sample.

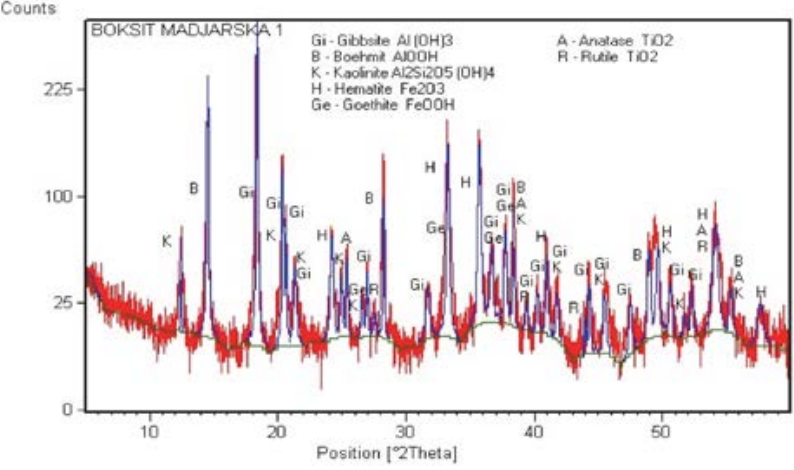

Figure 8. Diffractogram of the bauxite sample "Mađarska"

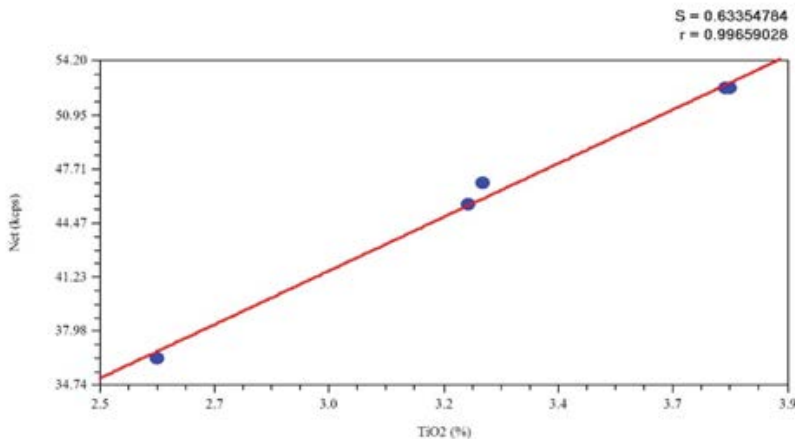

Figure 9. Calibration curve for the beads prepared by fusion

The equation for calculating the percentage (mass \%) of titanium dioxide in annealed bauxite was derived based on the calibration curve obtained for the beads resulting from fusion, Eq. (1):

$$
\begin{aligned}
\mathrm{TiO}_{2}(\text { annealed }) / \%= & 0.071917331 \times \\
& \text { Net }-0.035012049
\end{aligned}
$$

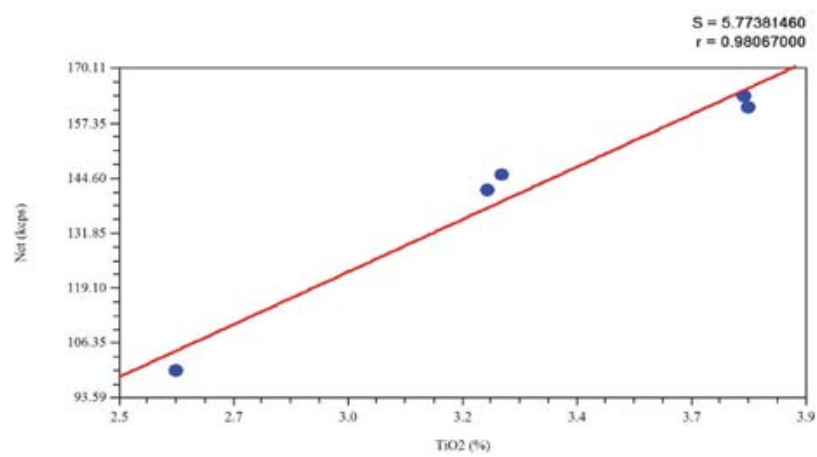

Figure 10. Calibration curve for the beads prepared by pressing

Another equation for calculating the percentage (mass \%) of titanium dioxide in annealed bauxite was also derived based on the calibration curve obtained for the beads resulting from the process of pressing, Eq. (2): 
$\mathrm{TiO}_{2}$ (annealed) $/ \%=0.019017877 \times$

$$
\mathrm{Net}+0.621131611
$$

The actual content of titanium dioxide in the samples of bauxite was calculated according to the following equation, Eq. (3):

$$
\mathrm{TiO}_{2} / \%=\mathrm{TiO}_{2} \text { (annealed) } / \% \times \frac{100-L O I_{1075 C}}{100}
$$

This calculation is based on the values of the loss on ignition (LOI) at $1075^{\circ} \mathrm{C}$ (Table 2).

Table 2. Loss on ignition for bauxites from different deposits

\begin{tabular}{lc}
\hline Bauxite & LOI $\left(\mathbf{1 0 7 5}{ }^{\circ} \mathbf{C}\right) / \%$ \\
\hline Brazil & 27.84 \\
Grčka & 12.12 \\
Mađarska & 19.05 \\
\hline
\end{tabular}

On the basis of the calibration curve, the samples of different deposits prepared by fusion and by pressing were recorded, and the content of $\mathrm{TiO}_{2}$ was calculated according to the above equations (Table 3 and Table 4).

Table 3. The content of $\mathrm{TiO}_{2}$ in bauxites from different deposits, calculated using a spectrophotometric and XRF method (by fusion)

\begin{tabular}{llll}
\hline Bauxite & \multicolumn{2}{c}{$\mathrm{TiO}_{\mathbf{2}}$ (mass \%) } & Residual \\
& Spectrophotometry & XRF & value \\
\hline Brazil & 1.267 & 1.3271 & 0.0601 \\
Grčka & 2.59 & 2.6219 & 0.0319 \\
Mađarska & 2.113 & 2.1829 & 0.0699 \\
$\bar{x}$ & - & - & 0.053966667 \\
S & - & - & 0.01972849 \\
\hline
\end{tabular}

Table 4. The content of $\mathrm{TiO}_{2}$ in bauxites from different deposits calculated using spectrophotometric and XRF method (by pressing)

\begin{tabular}{llll}
\hline Bauxite & \multicolumn{2}{c}{$\mathrm{TiO}_{2}$ (mass \%) } & Residual \\
& Spectrophotometry & XRF & value \\
\hline Brazil & 1.267 & 1.5703 & 0.3033 \\
Grčka & 2.59 & 2.6569 & 0.0669 \\
Mađarska & 2.113 & 2.3959 & 0.2829 \\
$\bar{x}$ & - & - & 0.2177 \\
S & - & - & 0.130994351 \\
\hline
\end{tabular}

The data presented here were obtained as a result of recording ten different beads from every sample, as well as recording a bead from each sample ten times. Moreover, ten samples for every bauxite were prepared for spectrophotometric analysis of the content of $\mathrm{TiO}_{2}$. The results for "Grčka" bauxite are shown in the tables below (Table 5, Table 6, and Table 7).

In order to check the precision of the XRF method for the beads prepared by fusion, a F-test was conducted,
Table 5. The content of $\mathrm{TiO}_{2}$ in ten different beads of the "Grčka" bauxite sample calculated using the XRF method (by fusion)

\begin{tabular}{llll}
\hline Bead & $\begin{array}{l}\text { Intensity } \\
\text { (kcps) }\end{array}$ & \multicolumn{2}{c}{ TiO $_{2}$ (mass \%) } \\
& annealed & not annealed \\
\hline 1 & 42.1089 & 2.99335 & 2.6304 \\
2 & 41.9086 & 2.97894 & 2.6178 \\
3 & 41.8425 & 2.97419 & 2.6136 \\
4 & 41.9263 & 2.98022 & 2.6189 \\
5 & 42.0063 & 2.98597 & 2.6239 \\
6 & 42.1625 & 2.99720 & 2.6338 \\
7 & 41.9912 & 2.98488 & 2.6229 \\
8 & 41.9809 & 2.98414 & 2.6223 \\
9 & 41.9748 & 2.98370 & 2.6219 \\
10 & 41.8317 & 2.97341 & 2.6129 \\
Min & 41.8317 & 2.97341 & 2.6129 \\
Max & 42.1625 & 2.99720 & 2.6338 \\
$\bar{x}$ & 41.97337 & 2.9836 & 2.6219 \\
S & 0.104991 & 0.007551 & 0.006622 \\
\hline
\end{tabular}

Table 6. The content of $\mathrm{TiO}_{2}$ in one bead of the bauxite sample

\begin{tabular}{|c|c|c|c|}
\hline \multirow{2}{*}{$\begin{array}{l}\text { Number } \\
\text { of measu- } \\
\text { rements }\end{array}$} & \multirow{2}{*}{$\begin{array}{l}\text { Intensity } \\
\text { (kcps) }\end{array}$} & \multicolumn{2}{|c|}{$\mathrm{TiO}_{2}(\operatorname{mass} \%)$} \\
\hline & & annealed & not annealed \\
\hline 1 & 42.1986 & 2.99980 & 2.6361 \\
\hline 2 & 42.0286 & 2.98757 & 2.6254 \\
\hline 3 & 41.9453 & 2.98158 & 2.6201 \\
\hline 4 & 42.2673 & 3.00474 & 2.6399 \\
\hline 5 & 42.2150 & 3.00098 & 2.6371 \\
\hline 6 & 42.2632 & 3.00444 & 2.6402 \\
\hline 7 & 41.9801 & 2.98408 & 2.6222 \\
\hline 8 & 42.2027 & 3.00009 & 2.6364 \\
\hline 9 & 42.2263 & 3.00179 & 2.6379 \\
\hline 10 & 42.0353 & 2.98805 & 2.6258 \\
\hline Min & 41.9453 & 2.98158 & 2.6201 \\
\hline Max & 42.2673 & 3.00474 & 2.6402 \\
\hline $\bar{x}$ & 42.13624 & 2.995312 & 2.6322 \\
\hline S & 0.124065 & 0.008924 & 0.00779 \\
\hline
\end{tabular}
"Grčka" calculated using the XRF method (by fusion)

Table 7. The content of $\mathrm{TiO}_{2}$ in ten different samples of "Grčka" bauxite calculated using spectrophotometric method JUS B.G8.514

\begin{tabular}{cc}
\hline Number of analysis & $\mathbf{T i O}_{\mathbf{2}}$ (mass \%) \\
\hline 1 & 2.69 \\
2 & 2.59 \\
3 & 2.54 \\
4 & 2.42 \\
5 & 2.58 \\
6 & 2.66 \\
7 & 2.55 \\
8 & 2.64 \\
9 & 2.64 \\
10 & 2.59 \\
Min & 2.42 \\
Max & 2.69 \\
$\bar{x}$ & 2.59 \\
$\mathrm{~S}$ & 0.076739096 \\
\hline
\end{tabular}


where the zero hypothesis tested was that the variances in the spectrophotometric method for calculating the content of $\mathrm{TiO}_{2}$ in bauxites-JUS B.G8.514 and in a non-standard XRF method were equal. The following value of the F-test was obtained:

$$
F=\frac{S_{1}{ }^{2}}{S_{2}{ }^{2}}, F=101,85, v_{1}=n_{1}-1, v_{2}=n_{2}-1
$$

Critical value at $\alpha=0.05, v_{1}=9, v_{2}=9$ is $\mathrm{F}_{9.9}=3.18$. The calculated result is considerably higher than the critical value, which means that the difference between the variances of the two methods is significant, and, with a risk of $5 \%$, the zero hypothesis on the equality of variances can be rejected. The standard method variance is higher than the XRF method variance, which leads to the conclusion that the XRF method is more precise.

The test of accuracy for the XRF method used in determining $\mathrm{TiO}_{2}$ was performed on the standard bauxite BXT-09, as well as compared to the same reference method. Ten beads of this standard were prepared by fusion and then recorded. The results obtained are given in Table 8 .

Table 8. The content of $\mathrm{TiO}_{2}$ in the certified bauxite sample BXT-09 determined by XRF method (by fusion)

\begin{tabular}{llll}
\hline Bead & $\begin{array}{l}\text { Intensity } \\
\text { (kcps) }\end{array}$ & \multicolumn{2}{c}{ TiO (mass \%) } \\
& annealed & not annealed \\
\hline 1 & 52.4692 & 3.73843 & 2.9608 \\
2 & 52.9908 & 3.77595 & 2.9906 \\
3 & 52.2886 & 3.72544 & 2.9505 \\
4 & 52.1599 & 3.71619 & 2.9432 \\
5 & 53.0883 & 3.78296 & 2.9961 \\
6 & 52.7425 & 3.75809 & 2.9764 \\
7 & 52.3993 & 3.73341 & 2.9569 \\
8 & 52.8240 & 3.76395 & 2.9811 \\
9 & 52.4176 & 3.73472 & 2.9579 \\
10 & 52.6323 & 3.75016 & 2.9701 \\
Min & 52.1599 & 3.71619 & 2.9432 \\
Max & 53.0883 & 3.78296 & 2.9961 \\
$\bar{x}$ & 52.60125 & 3.74793 & 2.9684 \\
S & 0.306229 & 0.022025 & 0.017461 \\
\hline
\end{tabular}

These results served as a starting point for the t-test, where the hypothesis on the equality of the reference value and the average value of the results was tested.

$$
|t|=\left|\frac{\mu-\bar{x}}{s}\right| \times \sqrt{n},|t|=2.096, v=n-1, \quad v=9
$$

Critical value at $\alpha=0.05, v=9$ is $\mathrm{t}=2.262$. Since $|t|<$ $|t|_{\text {critical }}$, with the risk of $5 \%$, the zero hypothesis can be accepted, and one can conclude, that the XRF method does not have a systematic error.

Testing the accuracy of the XRF method using the same reference method involved testing the hypothesis of equality of arithmetic means of the two methods. The following values were calculated for this purpose:

$$
\begin{aligned}
& t=\frac{\left(\bar{x}_{1}-\bar{x}_{2}\right)}{\sqrt{\frac{s_{1}{ }^{2}}{N_{1}}+\frac{s_{2}{ }^{2}}{N_{2}}}, t=-1,307} \\
& v=\frac{\left(\frac{s_{1}{ }^{2}}{N_{1}}+\frac{s_{2}{ }^{2}}{N_{2}}\right)^{2}}{\left(\frac{s_{1}{ }^{4}}{N_{1}{ }^{2}\left(N_{1}-1\right)}+\frac{s_{2}{ }^{4}}{N_{2}{ }^{2}\left(N_{2}-1\right)}\right)}, \quad v=9,18
\end{aligned}
$$

Critical value at $\alpha=0.05, v=9$ is $t=2.262$. Since in this case $|t|<|t|_{\text {critical }}$ the hypothesis of equality of arithmetic means of the two methods can be accepted and one can conclude, with the risk of $5 \%$, that the XRF method has no systematic error.

The following tables (Table 9 and Table 10) show results for "Grčka" bauxite sample obtained by measuring the beads prepared by pressing.

Table 9. The content of $\mathrm{TiO}_{2}$ in ten different beads of "Grčka" bauxite calculated using the XRF method (by pressing)

\begin{tabular}{lcll}
\hline Bead & $\begin{array}{c}\text { Intensity } \\
\text { (kcps) }\end{array}$ & \multicolumn{2}{c}{ TiO $_{2}$ (mass \%) } \\
& annealed & not annealed \\
\hline 1 & 126.1713 & 3.02064 & 2.6544 \\
2 & 125.9570 & 3.01657 & 2.6508 \\
3 & 126.4727 & 3.02637 & 2.6595 \\
4 & 126.4312 & 3.02558 & 2.6588 \\
5 & 126.2525 & 3.02219 & 2.6558 \\
6 & 126.6123 & 3.02903 & 2.6618 \\
7 & 126.3718 & 3.02445 & 2.6578 \\
8 & 126.1743 & 3.02070 & 2.6545 \\
9 & 126.4447 & 3.02584 & 2.6589 \\
10 & 126.3210 & 3.02349 & 2.6569 \\
Min & 125.9570 & 3.01657 & 2.6508 \\
Max & 126.6123 & 3.02903 & 2.6618 \\
$\bar{x}$ & 126.3209 & 3.023486 & 2.6569 \\
S & 0.188271 & 0.003579 & 0.003156 \\
\hline
\end{tabular}

Another F-test was conducted in order to test the precision of the XRF method for the beads prepared by pressing and the results were as follows:

$$
F=\frac{S_{1}^{2}}{S_{2}{ }^{2}}, F=453.93
$$

Again, the calculated value was considerably higher than the critical value, the difference between the variances of the two methods was significant and, with the risk of $5 \%$, the zero hypothesis on equality of the variances had to be rejected. The variance of the standard method was higher than the variance of the XRF method, which again leads to the conclusion that the latter is more precise. 
Table 10. The content of $\mathrm{TiO}_{2}$ in one bead of "Grčka" bauxite calculated using the XRF method (by pressing)

\begin{tabular}{|c|c|c|c|}
\hline \multirow{2}{*}{$\begin{array}{l}\text { Number } \\
\text { of measu- } \\
\text { rements }\end{array}$} & \multirow{2}{*}{$\begin{array}{l}\text { Intensity } \\
\text { (kcps) }\end{array}$} & \multicolumn{2}{|c|}{$\mathrm{TiO}_{2}($ mass \%) } \\
\hline & & annealed & not annealed \\
\hline 1 & 126.1205 & 3.01968 & 2.6536 \\
\hline 2 & 126.1848 & 3.0209 & 2.6546 \\
\hline 3 & 126.0728 & 3.01877 & 2.6528 \\
\hline 4 & 126.0922 & 3.01914 & 2.6531 \\
\hline 5 & 125.9905 & 3.01720 & 2.6514 \\
\hline 6 & 125.9390 & 3.01622 & 2.6505 \\
\hline 7 & 126.5761 & 3.02834 & 2.6612 \\
\hline 8 & 126.4619 & 3.02617 & 2.6593 \\
\hline 9 & 126.3677 & 3.02438 & 2.6577 \\
\hline 10 & 126.2962 & 3.02302 & 2.6565 \\
\hline Min & 125.9390 & 3.01622 & 2.6505 \\
\hline Max & 126.5761 & 3.02834 & 2.6612 \\
\hline $\bar{x}$ & 126.2102 & 3.021382 & 2.6551 \\
\hline S & 0.208899 & 0.003974 & 0.003499 \\
\hline
\end{tabular}

Testing the accuracy of the XRF method using the same reference method involved testing the hypothesis of equality of arithmetic means of the two methods. The following values were calculated for this purpose:

$$
\begin{aligned}
& t=\frac{\left(\bar{x}_{1}-\bar{x}_{2}\right)}{\sqrt{\frac{s_{1}{ }^{2}}{N_{1}}+\frac{s_{2}{ }^{2}}{N_{2}}}, t=-2,753} \\
& v=\frac{\left(\frac{s_{1}{ }^{2}}{N_{1}}+\frac{s_{2}{ }^{2}}{N_{2}}\right)^{2}}{\left(\frac{s_{1}{ }^{4}}{N_{1}{ }^{2}\left(N_{1}-1\right)}+\frac{s_{2}{ }^{4}}{N_{2}{ }^{2}\left(N_{2}-1\right)}\right)}, \quad v=9,04
\end{aligned}
$$

Critical value at $\alpha=0.05, v=9$ is $\mathrm{t}=2.262$. Since in this case $|t|>|t|_{\text {critical }}$, then, with the risk of 5\%, the hypothesis of the equality of arithmetic means of the two methods must be rejected. It can be concluded that the XRF method for the beads prepared by pressing does not yield the same average value as the reference method, which means that it shows a systematic error.

The test of accuracy for the XRF method for determining $\mathrm{TiO}_{2}$ for the beads prepared by pressing was conducted using the reference bauxite B 010 . Ten beads were prepared and recorded. The data obtained are given in Table 11.

These values served as the basis for the t-test and the hypothesis on equality of the reference value and the average value of the results investigated.

$$
|t|=\left|\frac{\mu-\bar{x}}{s}\right| \cdot \sqrt{n},|t|=316.389, \quad v=n-1, \quad v=9
$$

Critical value at $\alpha=0.05, v=9$ is $\mathrm{t}=2.262$. Since $|t|>$ $|t|_{\text {critical, }}$, the zero hypothesis can be rejected, with the risk of

\begin{tabular}{|c|c|c|c|}
\hline \multirow[t]{2}{*}{ Bead } & \multirow{2}{*}{$\begin{array}{l}\text { Intensity } \\
\text { (kcps) }\end{array}$} & \multicolumn{2}{|c|}{$\mathrm{TiO}_{2}($ mass \%) } \\
\hline & & annealed & not annealed \\
\hline 1 & 140.4317 & 3.29184 & 2.9245 \\
\hline 2 & 139.7303 & 3.27851 & 2.9126 \\
\hline 3 & 140.0871 & 3.28529 & 2.9187 \\
\hline 4 & 140.2406 & 3.28821 & 2.9212 \\
\hline 5 & 140.3696 & 3.29066 & 2.9234 \\
\hline 6 & 140.4510 & 3.29221 & 2.9248 \\
\hline 7 & 139.9880 & 3.28341 & 2.9169 \\
\hline 8 & 140.3402 & 3.29010 & 2.9229 \\
\hline 9 & 140.1154 & 3.28583 & 2.9191 \\
\hline 10 & 140.0452 & 3.28449 & 2.9179 \\
\hline Min & 139.7303 & 3.27851 & 2.9126 \\
\hline Max & 140.4510 & 3.29221 & 2.9248 \\
\hline $\bar{x}$ & 140.1799 & 3.287055 & 2.9202 \\
\hline S & 0.229043 & 0.004353 & 0.003881 \\
\hline
\end{tabular}

Table 11. The content of $\mathrm{TiO}_{2}$ in the reference bauxite sample $\mathrm{B} 010$ calculated using the XRF method (by pressing)

$5 \%$, and it can be concluded that the XRF method in this case shows a systematic error.

\section{Conclusions}

Based on recording the intensities of the beads made from certified reference bauxite samples, prepared by fusion, the calibration curve was obtained with the correlation coefficient of $r=0.9966$ and the standard deviation of $S=0.6335$. For the samples prepared by pressing, the calibration curve obtained had the correlation coefficient $r=0.9807$ and the standard deviation $S=5.7738$. The calibration curve was the basis for the equation used for calculating the content of $\mathrm{TiO}_{2}(\%)$ in the bauxite samples for both methods of bead preparation. The average residual value between the content of $\mathrm{TiO}_{2}$ calculated using the XRF method and the reference method JUS B.G8.514 was 0.054, with the standard deviation of 0.019 , for the beads obtained by fusion, and 0.218 , with the standard deviation of 0.131 for the beads obtained by pressing. The XRF method was then tested for precision and accuracy. The F-test results show, with the risk of $5 \%$, that the zero hypothesis on the equality of variances can be rejected. The standard method variance is higher than the XRF method variance for both fused and pressed beads, which leads to the conclusion that the XRF method is more precise. A t-test was conducted to test the accuracy (using the reference method and the standard bauxite samples BXT-09 and B 010) for the beads obtained by fusion and by pressing. In the case of the beads prepared by fusion, it can be concluded, with the risk of $5 \%$, that the reference values and the average values of the results investigated were equal, that the arithmetic means of the two methods showed no differences, and 
that the method did not have any systematic errors. As far as the pressed beads are concerned, it can be concluded, with the risk of $5 \%$, that the arithmetic means of the two methods differed, as well as the reference and the average values of the results investigated, and that the XRF technique for this method of bead preparation showed a systematic error.

Based on the results obtained, it can be concluded that the XRF, as a method for calculating the content of $\mathrm{TiO}_{2}$ in bauxite, is precise and accurate when beads are prepared by fusion. For the beads prepared by pressing, this method shows a systematic error, which is a consequence of insufficient homogeneity of the sample.

\section{References}

1. F. M. Meyer, Nat. Resour. Res., 2004, 13, 161-172. DOI:10.1023/B:NARR.0000046918.50121.2e

2. M. Authier-Martin, G. Forte, S. Ostap, J. See, JOM, 2001, 53, 36-40. DOI:10.1007/s11837-001-0011-1

3. J. E. Kogel, R. C. Nikhil, in J. E. Kogel (Ed.): Industrial Minerals and Rocks: Commodities, markets and Uses, Elsevier, New York, 2006, pp. 225-269.

4. R. Vračar, Ž. Živković, Ekstraktivna metalurgija aluminijuma, Naučna knjiga, Belgrade, Serbia, 1993, pp. 1-14.

5. J. Q. Li, Y. Zou, C. Y. Chen, Y. Z. Jia, Adv Mat Res, 2013 , 1124-1127.

DOI:10.4028/www.scientific.net/AMR.734-737.1124

6. G. Alkan, C. Schier, L. Gronen, S.Stopic and B. Friedrich, Metals, 2017, 7, 458. DOI:10.3390/met7110458

7. H. Mahmoud, A. Abdel-Lateef, A. Attiah, J. Anal. Sci., Methods Instrum., 2013, 3, 62-66. DOI: 10.4236/jasmi.2013.31007

8. T. M. Sørlie,G. Wibetoe, Anal Bioanal Chem, 2003,376, 721727. DOI:10.1007/s00216-003-1938-6

9. M. Gawrys, J. Golimowski, Analytica Chimica Acta, 2001, 427, 55-61. DOI:10.1016/S0003-2670(00)01183-1

10. R. L. Njinga, M. N. Moyo and S. Y. Abdulmaliq, Int. J. Agron., 2013, 2013, 1-9. DOI:10.1155/2013/156520
11. R. K. Mondal, P. K. Tarafder, Microchim. Acta,2004, 148, 327333. DOI: $10.1007 /$ s00604-004-0272-9

12. V. Srilalitha, A. R. G. Prasad, K. R. Kumar, V. Seshagiri, L. R. K. R. Ravindranath, Facta Univ., Ser.: Phys., Chem. Technol., 2010, 8, 15-24. DOI: 10.2298/FUPCT1001015S

13. H. Z. Mousavi, N. Pourreza, J. Chin. Chem. Soc., 2008, 55, 750-754. DOI:10.1002/jccs.200800112

14. B. Xing, X. Liu, Z. Zhang, K. Wang and K. Li, Commun. Soil Sci. Plant Anal., 2005, 35, 1839-1850.

DOI:10.1081/LCSS-200026803

15. D. N. Stratis, K. L. Eland, S. M. Angel, Appl. Spectrosc., 2000, 54, 1719-1726. DOI:10.1366/0003702001948871

16. P. J. Potts, A Handbook of Silicate Rock Analysis, Springer, Boston, MA, 1992, pp. 226-285.

DOI:10.1007/978-1-4615-3270-5

17. S. Jagadeeswari, P. D. Devi, Asian J. Appl.Sci.Technol., 2017, 1, 196-198.

18. Z. W. Chen., M.W. Gibson, H. Huang, X-Ray Opt. Instrum., 2008, 8, 1-10. DOI:10.1155/2008/318171

19. B. K. Gan, Z. Taylor, B. Xu, A. Riessen, R. D. Hart, X. Wang and P. Smith, Int. J. Miner. Process., 2013, 123, 64-72.

DOI:10.1016/j.minpro.2013.05.005

20. F. S. Oliveira, A. F. D. C. Varajão, C. A. C. Varajão, B. Boulangé, C.C. V. Soares, Catena, 2013, 105, 29-39.

DOI:10.1016/j.catena.2013.01.004

21. A. I. Assem, H. A. Nasr-El-Din, J. Pet. Sci. Eng., 2017, 158, 441-453. DOI:10.1016/j.petrol.2017.08.075

22. E. R. Passos, J. A. Rodrigues, Ceramica, 2016, 62, 38-44. DOI:10.1590/0366-69132016623611960

23. R.-X. Liu, C.-S. Poon, J. Cleaner Prod., 2016, 112, 384-391. DOI:10.1016/j.jclepro.2015.09.049

24. F. M. Kaußen, B. Friedrich, Hydrometallurgy, 2018, 176, 4961. DOI:10.1016/j.hydromet.2018.01.006

25. N. Yalçın, V.Sevinç, Ceram. Int., 2000, 26, 485-493. DOI:10.1016/S0272-8842(99)00083-8

26. A. G. Revenko, X-Ray Spectrom., 2002, 31, 264-273. DOI:10.1002/xrs.564

26. M. F. Gazulla, M. P. Gómez, A. Barba and J. C. Jarque, X-Ray Spectrom., 2004, 33, 421-430. DOI:10.1002/xrs.743

\section{Povzetek}

$\mathrm{V}$ boksitih iz različnih depozitov smo določali delež $\mathrm{TiO}_{2}$ (masni \%) z X-žarkovno fluorescenčno spektrometrijo (XRF) in $\mathrm{z}$ referenčno spektrofotometrično metodo JUS B.G8.514. Vzorce smo pripravili na dva načina: tehnika fuzije $\mathrm{z}$ boraksom in stiskanje, zatem pa smo za namen analize oblikovali kroglice. Za pripravo umeritvene krivulje smo uporabili certificirane referenčne standarde boksita. Enačbo za izračun deleža $\mathrm{TiO}_{2}$ (masni \%) v vzorcih boksita smo izpeljali iz umeritvene krivulje. Rezultate XRF metode smo statistično testirali z uporabo F-testa in t-testa (s standardnim vzorcem boksita in $\mathrm{z}$ referenčno metodo). Vrednosti iz zgoraj navedenih testov za kroglice po fuziji so pokazale, da je XRF metoda natančna in pravilna ter da nima sistematskih napak, medtem ko je za kroglice po stiskanju ta metoda pokazala signifikantno sistematsko napako. 